\title{
Above the Fray? The Use of Party System References in Presidential Rhetoric
}

\author{
JOHN J. COLEMAN \\ University of Wisconsin-Madison \\ PAUL MANNA \\ College of William and Mary
}

\begin{abstract}
Examining communication items from four presidents, we find that presidents link themselves to the party system rhetorically. Employment of party references is tested against recurrent features of the office and shifts in the political environment, including presidential approval, partisan independence, presidential successes and defeats in Congress, and the presence of divided government. Presidents strategically employ party system references with regard to audience and calendar. We find greater support for the rhetorical president as politician rather than as statesman above the fray, and we consider our findings in relation to the concept of political time. These findings suggest rethinking accounts of the contemporary presidency that presume that presidents determinedly place themselves "above politics" and "beyond party" when crafting their communications imagery.
\end{abstract}

The relationship between the president and political parties has generated significant scholarly controversy. Prominent proponents of responsible political parties have argued that presidents provide critically important party leadership (Burns 1963; Schattschneider 1942). Other scholars have worried about the impact of presidential power on the broader party system (Coleman 1996; Milkis 1993). Some analysts show that presidents seek to present themselves as beyond the clutches of party; others suggest that presidents are inherently engaged in the construction and reconstruction of party systems and consider party "ownership" of issues as they formulate electoral strategy (Geer 1998; Kernell 1986; Skowronek 1993; Petrocik 1996).

John J. Coleman is a professor of political science at the University of Wisconsin-Madison. He is the author of Party Decline in America: Policy, Politics, and the Fiscal State and various articles, and coeditor of several books.

Paul Manna is an assistant professor of government and faculty affliate in the Thomas Jefferson Program in Public Policy at the College of William and Mary and is the author of School's In: Federalism and the National Education Agenda.

AUTHOR'S NOTE: We wish to thank Teresa Gorbett for excellent research assistance. 
Studies of presidential-congressional relations show that American institutional structure significantly affects the interaction between presidents and parties (Binder 1999; Bond and Fleisher 1990; Brady and Volden 1998; Cameron 2000; Coleman 1999; Davis 1992; Edwards 1989; Edwards and Wayne 1990; Gilmour 1995; Harmel 1984; James 2000; Jones 1994, 1999; Krehbiel 1998; Peterson 1990; Seligman and Covington 1989). Presidents cannot always assume the support of their fellow party members and must seek support from the opposition party, particularly when filibusters are a threat. Divided government, the norm since 1969, increases the necessity of opposition party support if the president is to succeed legislatively. There are, then, strategic institutional reasons to expect presidents to downplay narrow portrayals of partisan advantage. Any partisan strategy must accommodate the institutional pressures that push presidents toward bipartisan cooperation (Jones 1994). ${ }^{1}$

Scholars have also argued that presidents are interested in building linkages beyond their party in arenas outside Congress. Milkis (1993) presents the post-New Deal president not so much as partisan or bipartisan but seeking to insulate himself above all forms of partisanship by institutionalizing his policy successes. Institutionalization is not the only available road for improving the chance of policy success, however: presidents, fearing their party ties in Congress are unreliable, perceive incentives to "go public" to place pressure on Congress from without (Kernell 1986; Miroff 1995; Ostrom and Simon 1990; Rockman 1984; Rose 1988). By going public, presidents portray themselves as outside the party maneuvers occupying Congress and urge the public to demand that legislators rise above narrow partisan concerns. Barrett (2005) notes that presidents are especially prone to making numerous rhetorical appeals when they support pending legislation, especially when they have proposed it. The president presents himself as the tribune of the people rather than of any party's agenda. In these accounts, presidents go public to serve strategic needs (Canes-Wrone 2006; Cohen 1995; Cohen and Hamman 2003; Druckman and Holmes 2004; Edwards 2003; Edwards, Mitchell, and Welch 1995; Hetherington 1996; Krosnick and Kinder 1990; Lewis 1997; McGraw, Best, and Timpone 1995; Miroff 1995; Ostrom and Simon 1989; Pauley 1998; Ragsdale 1987; Shields and Goidel 1998; Wood, Owens, and Durham 2005; Zarefsky 2004). They change their activities (e.g., speeches, travel) to shift public perceptions and enhance approval, hoping in turn that higher approval will generate success in Congress. Results have been mixed but mostly skeptical on both linkages, particularly the connection between approval and congressional success (Collier and Sullivan 1995; Edwards 1995; Edwards and Wood 1999; Gleiber and Shull 1992; Jones 1994; Mouw and MacKuen 1992; Rockman 1984).

Surprisingly, despite this large literature exploring important themes, patterns, styles, and verbal strategies in presidential communication and leadership, few studies address directly and explicitly the frequency and manner by which presidents rhetorically portray their connection to the party system. In Neustadt's classic study (1990), public prestige is presented as one of the three major pillars of presidential influence, and presidents can

1. There is a huge literature on these issues. Most studies focus on the outcomes of presidential and party interactions in areas such as legislative success, party cohesion, and election coattails. Jones (1994, 1999) suggests that presidential-congressional policy making can be partisan, copartisan, crosspartisan, or bipartisan. 
enhance this prestige by appearing to be above the political fray (see also Brace and Hinckley 1993; Conti 1995; Fett 1992; Hager and Sullivan 1994; Ostrom and Simon 1990; Roelofs 1992; Wayne 1998). Key studies by Tulis (1987), Kernell (1986), and Hart (1987) suggest that modern presidents employed rhetoric to develop new images and relationships with the public that extended beyond party. Whittington (1997) argues that the rhetorical presidency, arising out of a Progressive view that parties corrupt and thwart the will of the people, is intimately related to changes in the party system: a direct presidential relationship with the people would cure the disease of corrupt partisan intermediation. Rottinghaus (2006) finds signs of this direct relationship by measuring the congruency of presidential statements about policy with public opinion.

These studies implicitly assume much about presidents' portrayal of themselves in the party system, but none deals directly with the partisan substance of presidential statements over time. Hinckley (1990), offering the most extensive examination, finds presidents eager in inaugural addresses and major speeches to present themselves as nearly entirely divorced from the electoral system. Lim (2002) contends this tendency has grown stronger over the course of U.S. history. Jarvis (2004) finds rhetorical differences between Democratic and Republican presidential candidate post-Labor Day campaign speeches, with Democrats more likely to mention groups such as the party or constituents and Republicans more likely to focus on values and ideals. The party difference, from 1948 to 2000, is substantively modest and diminishing.

The broadest consensus is that arguably weakening partisan loyalties in the public and an electoral base somewhat independent of fellow partisans in Congress provide presidents with incentives to portray themselves in their communications as above the political fray and virtually above or outside the system of partisanship and elections altogether. As Ragsdale (1995, 41) puts it,

The single executive image endures in presidents' own words, public impressions, and press coverage. In their speeches, presidents offer the country the single executive image. They sponsor the dual notions of presidential omnicompetence and omnipresence. They suggest that they alone are linked to the American people, above politics, beyond party, and touched by God. ${ }^{2}$

How frequently and in what manner do presidents portray their connection to the party system? Rather than focus on whether the president makes a speech under a given set of circumstances, which much literature has examined, we study the partisan content of the president's messages. What does the president say about parties and when does he say it? Do presidents in fact seek to stand alone, above politics and beyond party?

An array of literature assumes that the president has many reasons to remain distant from the parties in his communications, and some arguments in the presidency literature, as discussed above, effectively depend on this assumption. If that assumption is incorrect, the literature in some aspects may fundamentally err in its portrayal and understanding of

2. Although not directly examining Ragsdale's point, Canes-Wrone (2006) observes that presidents do in fact tend to take to the airwaves for policies they believe will improve societal welfare; she also finds that the conditions under which presidents pander to public opinion are relatively narrow. 
the contemporary presidency. We argue that the established understanding both theoretically and empirically underestimates the degree to which presidents link themselves to the party system. Just as the literature on presidential public activity suggests that presidents alter their public behavior, including travel and speeches, partly in reaction to the political environment, the same may be suggested for the partisan content of presidential behavior. Presidents strategically employ general party-related references and specific references to the virtues of partisanship and bipartisanship. Two groups of factors influence the use of these varied references: the shifting political environment, including public approval and congressional success and failure, and recurrent features of the office such as diverse elite and nonelite audiences, a variety of communication modes, and the electoral calendar. We also speculate on the president's rhetoric as a reflection of political time.

\section{Presidential Connections to the Party System}

Studies of presidential-congressional relations and presidential attempts to go public or otherwise circumvent party politics jointly suggest that, at least in part, structural constraints determine a president's connection to the parties. As suggested above, presidents and scholars see two central parts of the president's political environment-his relationship with the public and his relationship with Congress - as especially critical influences on the president's policy and political success. Shifting political currents concerning these two relationships can affect the frequency and nature of his rhetorical linkages to the party system.

Considering first the public relationship, people may more readily receive partyrelated language at some times rather than others. With a public skeptical or hostile toward political parties, for example, presidents might be wary of any extensive rhetorical linkage to parties. Moreover, a popular president may perceive little need to appear connected to the broader party system or emphasize heavily the virtues of partisanship or bipartisanship. Instead, this president can leverage his popularity to appear, in Ragsdale's phrase, "above politics, beyond party, and touched by God.” The popular president with high approval ratings is better positioned than other presidents to stress the individual basis of his accomplishments and his governance. Improvements in presidential approval should reduce the probability that presidents make party-related references of any kind or references to partisan and bipartisan virtues specifically. The flip side is that presidents floundering in public disapproval may seek the shelter of closer links to the party system. In his 2006 State of the Union address, for example, President George W. Bush made eight explicit references to bipartisanship or the problems with partisanship. In 2002 and 2003, in the midst of much higher approval ratings, he made but three and one, respectively. More general references to working together were also more frequent in 2006 than the earlier two years.

The president's relationship with Congress creates a second set of structural constraints. If the opposition party controls one or both houses of Congress, presidents may adjust their party-related references. Although the volume of these references might not change, presidents may wish to emphasize the virtues of bipartisanship more than the virtues of their own particular party when at least part of the legislature is in rival party hands. 
The president's success in Congress, which is likely to vary during his term, is another constraint that may affect the president's use of party-related references. Presidents, as the focal point of public attention, obviously much prefer to be associated with success rather than with failure. With regard to Congress, a president should rhetorically separate himself from parties when the party system produces substantial numbers of defeats for him and embrace the system when he is victorious. Congressional victories for the president should lead to increases in party-related references generally and references to the virtues of partisanship or bipartisanship specifically.

These strategies associated with congressional failure and success serve two purposes for the president. First, they elevate the president above congressional failure by decreasing the rhetorical linkage between the president and the party system when the president suffers losses. The president hopes, in effect, to shift blame to legislators and away from himself. Second, they allow the president to reward members of Congress for their efforts in passing his program when he is victorious. Here, the president shares the credit claiming with deserving members of Congress, including those in his own party and the opposition. Unlike with the public, where the president might possibly want to appear the figure above the fray, fellow political elites expect the president to replenish their political capital when they provide him with victories. Given some connection between the electoral fate of presidents and other party members (Aldrich 1995; Campbell 1993; Cox and McCubbins 1993), presidents have to help define the party brand name: their future success, as part of a repeated game rather than a one-shot interaction with Congress, will depend on it. A president claiming sole credit for congressional achievements at one moment in time would increasingly find it difficult to generate congressional cooperation in the future. ${ }^{3}$ This approach also serves the president's longterm strategic purposes by sending signals that legislators will be politically isolated if they thwart the president and embraced if they assist him.

In addition to structural factors in the public and congressional political environment, recurrent institutional features of the presidency are also likely to influence a president's employment of party-related references. One of these recurrent features is the diverse range of audiences that presidents entertain. We suggested earlier that, although the president may wish to appear above the fray, sometimes he must tie himself to the party system to help members of Congress or because he is sinking under low public approval. Members need the president to tout their efforts, which he can do by publicly emphasizing the role of party members or the parties in general in accomplishing some goal. Elites need less tutoring than the public on the role of parties and partisans in the legislative process, so we can expect presidents to emphasize party more in their communication to the public than to governing elites. The president's expected service as a

3. Former House Speaker Tip O'Neill $(1987,308)$ notes that, although he had some problems with staffers in the Kennedy administration, "at least they looked after the Democratic members of Congress. Their attitude was: we want you to be reelected and we're working to help you. But during the Carter years, congressional Democrats often had the feeling that the White House was actually working against us." O'Neill (1987, 305-29) complains that he insisted that Carter and his staff fully communicate with Congress, especially Democrats, as equal partners, but that did not happen, and resentment and anger toward the White House built steadily during Carter's term. 
party leader also extends to communication with partisan groups. Presidents should make frequent party-related references before party audiences.

A second recurrent reality facing presidents is the campaign calendar. During election season, presidents are expected by fellow partisans to assist the party's overall bloc as well as specific individual candidates. For the four months from August through November, when Congress is normally out of session and election season is in full swing, campaign politics should boost the probability of verbal linkages to the party system, especially reference to party virtues, and diminish the probability of presidential appeals featuring bipartisan virtues.

In sum, the discussion in this section generates six hypotheses regarding presidents' rhetorical linkages to the party system. The first two consider recurrent institutional features of the office; the remainder consider the shifting political environment.

Audience signals hypothesis: Presidents will make party-related references least frequently to other governing elites, more frequently to the public, and most frequently to party groups.

Campaign calendar hypothesis: Presidents are more likely to make party-related references from August through November of an election year, particularly references stressing the virtues of partisanship.

President as statesman hypothesis: Presidents seek to portray themselves as above the political fray when the public approves of their job performance. Increases in presidential approval reduce the probability that a presidential communication contains a partyrelated reference. Declines in presidential approval increase the probability of a partyrelated reference.

Public partisanship bypothesis: The less the public identifies with one of the major political parties, the lower the probability of party-related references and references to the virtue of partisanship. References to the attractions of bipartisanship should increase.

President as politician bypothesis: Presidents let members of Congress know that members will share in the credit for successes but stand alone during defeats. The probability of a presidential communication referencing the party system increases with presidential victories and declines with defeats.

Institutional control bypothesis: Divided government will decrease the probability of party-related references and references to the virtues of the president's party. Divided government will increase the probability of references to bipartisanship.

\section{Data and Variables}

We content analyzed presidential communications during the first terms of the Dwight Eisenhower, Jimmy Carter, Ronald Reagan, and George W. Bush presidencies for party-related references. These four presidents provide a structured range of similarities and contrasts on variables that plausibly relate to how presidents connect themselves to the party system. This case selection strategy is a conservative approach: it should be more difficult to find patterns that persist across these cases than it would be with a group of presidents facing roughly similar political, economic, and issue contexts. 
How do these presidents compare? As Table 1 indicates, all four entered office after control by the other party, each faced significant economic adversity during their tenure, and all faced serious foreign-policy challenges. These similarities are noteworthy, but their differences are more striking. Eisenhower and Carter pursued the presidency as outsiders to Washington's elected political circles and outsiders to their respective national party structures. Reagan, on the other hand, was a veteran national Republican party insider since his famous endorsement of Barry Goldwater in 1964, and Bush was well acquainted with the power centers and leading figures in the national Republican party. Even if they chose to position themselves as critics of Washington, as candidates of major and minor parties alike frequently do, that does not equate to being a party outsider. Eisenhower, Reagan, and Bush were Republicans elected to a second term; Carter, a Democrat, lost his reelection bid in 1980. Carter, Reagan, and Bush served as governors prior to running for the presidency; Eisenhower had no elected experience. Eisenhower and Reagan won easy popular vote pluralities, Carter's plurality was thin, and Bush lost the popular vote. Eisenhower, Carter, and Bush reigned over unified government (Eisenhower two years, Bush about two and a half, and Carter all four). Carter's party majority was substantially larger than that of Eisenhower or Bush or the Republican Senate under Reagan. The four served in different media eras, with Eisenhower at the beginning of the television age and the public presidency, Carter and Reagan serving with television as the predominant source of news for most Americans, and Bush serving after the explosion of talk radio and the Internet (see Hart 1987; Kernell 1986). Finally, each entered office in a different mode of "political time" as defined by Stephen Skowronek (1993), with Eisenhower entering during a context of preemption; Carter, disjunction; Reagan, reconstruction; and Bush, articulation. Carter and Reagan stand alone in the postwar period as examples of their particular presidential types.

We created our dependent variables by coding communication items from the Public Papers of the Presidents. ${ }^{4}$ Coded items included speeches, addresses, and remarks; press conferences and reporter interviews; bill signings; letters and messages to Congress and congressional leaders; and veto messages. We excluded toasts at dinners with foreign and domestic officials; joint communiqués; and the text of executive orders, proclamations, and policy fact sheets (presidential remarks related to these orders, proclamations, and sheets were coded). The types of communication items we examined help create the president's public image and also, singly or in combination, appear in other studies of presidential activities and influence. Rather than select communication items of only one type or of typically high publicity and prominence, we chose to examine party-related rhetoric across presidential communication more broadly. For the four presidents, we included 4,462 items. ${ }^{5}$

4. Coding protocol is available from the authors.

5. Hinckley (1990) makes a compelling case that postwar presidents divorce themselves from the partisan and electoral world in building their public image, but her study of presidential communication relies primarily on major addresses by the president. Although these are the most visible presidential activities for most Americans, the president builds his image through other activities as well, and the data here rely on that fuller portrait. 


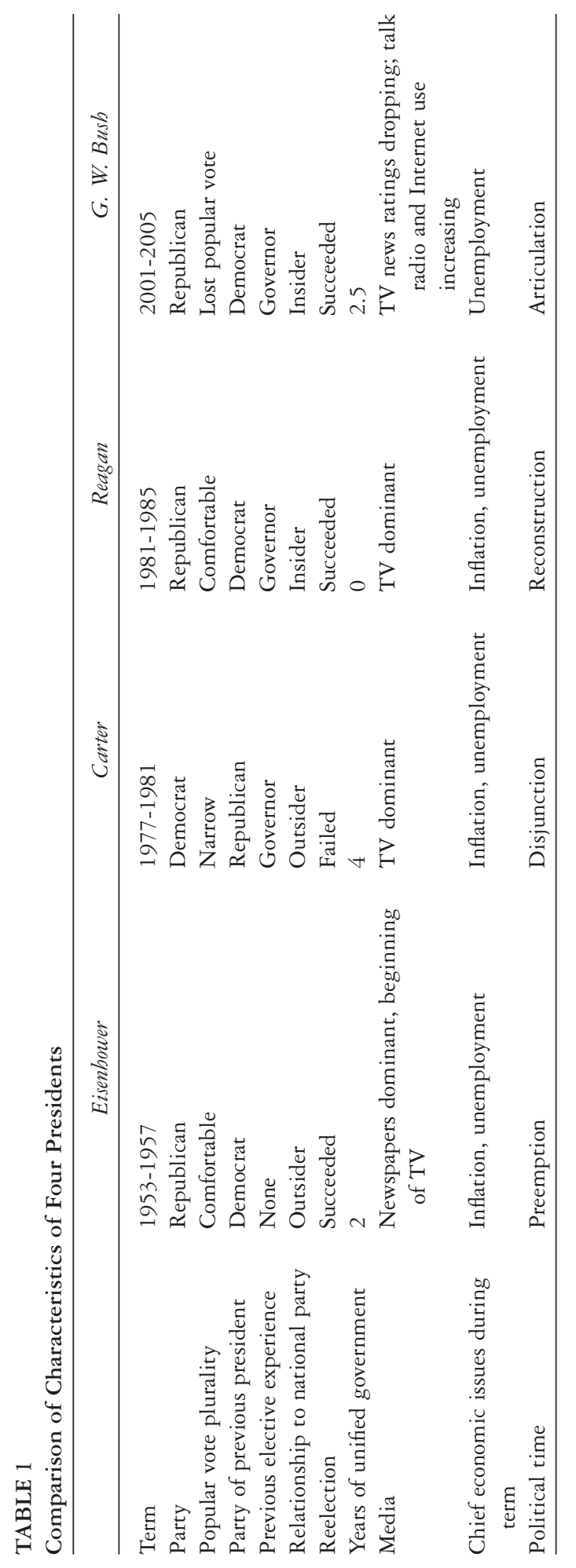


From these items, we constructed four measures of rhetorical linkage to the party system. First, each communication item was reviewed for party-related references. Such references include use of terms directly stating or implying support for a particular party or bipartisanship ("party politics," "both sides of the aisle," "accomplishments of party leaders," "rise above party," linking oneself to past presidents of one or both parties, and so on). ${ }^{6}$ The Appendix provides examples of these references. Party-related references also include criticisms of partisanship, interpretations of electoral mandates, and electoral support for party candidates. Any item making a party-related reference was coded "1." If the item did not make party-related references, coding ceased and the item was coded "0."

When an item did make party-related references, up to three "nature of reference" codes were entered. ${ }^{7}$ We employed fifteen coding categories for nature of reference:

1. positive reference to a party and economic policy or performance

2. positive reference to a party and foreign policy or performance

3. positive reference to a party in other policy areas (e.g., social issues, education, health)

4. general statements about the positive attributes of a party

5. claims of a party mandate after an election

6-10. same as 1-5, respectively, except refers to bipartisanship

11. complaints about congressional partisanship

12. general corruptness of partisanship

13. executive-legislative relations not clearly pro-partisan or pro-bipartisan

14. offering electoral support for the party

15. miscellaneous references.

We constructed the remaining three measures of rhetorical linkage from the nature of reference codes. For virtues of partisanship, we coded " 1 " if any of the three references were coded as categories 1-4 above and a "0" otherwise. For virtues of bipartisanship, we coded a " 1 " if any of the three references were coded as categories 6-9 and a " 0 " otherwise. This coding scheme allows a communication item to be coded as stressing the virtues of both partisanship and bipartisanship if, for example, in a single speech, a president stressed partisan and bipartisan themes. ${ }^{8}$

6. A presidential statement that an issue "is not a partisan issue" or "is not a Democratic or Republican issue" is coded as a bipartisan reference. Arguably, statements of this type could be considered separately as nonpartisan rather than bipartisan. In practice, however, the distinction is minimal: the president is calling for the parties to work together and to eschew partisan motivations. Nonpartisan statements are also potentially a very broad category-any reference to "the federal government" or "the United States" or "we need to," for example, might be included.

7. Because the nature of reference code was cut off at three, the relevant unit of analysis in this article is the item (case) rather than the individual references. Our concern was with the frequency of presidents' rhetorical linkages to the party system, rather than the number or length of these linkages. Across items, the amount of emphasis varies. For example, considering Eisenhower's communication items that make party references, on average about 9 percent of the paragraphs in those items refer to party. In two thirds of the items (one standard deviation), up to about 19 percent of the paragraphs refer to party. For Carter, by comparison, the percentages are 15 and 32, respectively.

8. Coding category 13 typically included references where presidents discussed working with Congress. Unless the party-related nature of the president's executive-legislative reference was clearly stated or strongly implied in the communication item, we did not include these references to cooperation between 
For independent variables, we use the movement in the president's Gallup approval rating over the previous two months to measure change in presidential approval. ${ }^{9}$ In other words, the change in the president's approval rating from March to April would be the context for presidential communication items in May. ${ }^{10}$ Public partisanship is the percentage of the public that identifies as "Independent" in the preceding National Election Study; therefore, it is a measure of stated partisan independence. We use this variable as a proxy for public distance from or skepticism toward the party system.

To measure the impact of recent legislative history on presidential linkage to the party system, we include the number of congressional votes in the previous month that went against the president's stated position and the number of votes that supported the president's position. For a presidential statement in May, for example, the legislative context is his success and failure in April. Because failure in either chamber will effectively derail the president's stated preference, we use the total number of legislative defeats and victories rather than separating by chamber. ${ }^{11}$ We employ the number of wins and losses rather than the percentage of victories because the former better conveys a sense that the president is besieged or riding a wave of victories. That is, losing fifteen of fifteen votes should typically convey a greater sense of legislative futility than losing two of two votes, but using percentages would mask the differential futility: 100 percent equals 100 percent. Of course, there will be times when a single defeat might be more damaging than five or ten other defeats, but for present purposes we presume that any defeat of the president's position is damaging and any victory encouraging. Each win or loss is therefore weighted equally in computing the tally.

Party control is measured by a dummy variable for the presence of divided government. Our testing with alternative specifications — number of chambers controlled by the president's party, size of the majority party, and so on-did not significantly affect the results, with the exception of adding additional collinearity in some estimations.

Lastly, we control for the audience, campaign calendar, and length of presidential communication items. We include dummy variables indicating whether the public is the primary audience for a presidential communication item, a political party group is the primary audience, and whether the communication item was delivered in August through November of an election year. Finally, in longer communication items, presidents have more opportunities to make party-related references, so we include a standardized control for item length.

the executive and legislative branches in the overall party-related reference variable and do not analyze them in this article. A table of results regressing all references to executive-legislative cooperation on our model is available from the authors.

9. If Gallup took more than one reading, we take the mean value of the approval rating. If there was no reading for a particular month, we interpolated the value.

10. Alternative specifications including the actual level of approval or both the level and change in approval had no significant effect on the results.

11. We ran models including the separate numbers of wins and losses for the two chambers. The results showed little change in the direction of the coefficients compared to the results with the total number of wins and losses. The direction of every significant coefficient in the models employing the separate chamber data was in the direction discussed in the text for the total wins and losses estimations. 


\section{The Contours of Presidential Connection to the Party System}

We begin by describing in general presidents' party-related references. Table 2 shows that presidents do link themselves to the party system. Carter makes party-related references in slightly under 30 percent of his communications; Eisenhower in over 40 percent; and Reagan and Bush, the party insiders (see Table 1), around 50 percent. Considering only the set of communication items in which the president makes a party-related reference, Carter is more likely to emphasize the virtues of partisanship than bipartisanship, whereas the other three presidents are more likely to stress the virtues of bipartisanship. President Bush stands out on this comparison, referencing bipartisanship five times more frequently than partisanship. This is not a 9/11 effect: both before and after September 11, Bush's references to the virtues of bipartisanship were equally frequent. Bush, Reagan, and Eisenhower at times-in about 15 to 37 percent of the items in which they make a party reference - take a critical view of partisanship, seeing it as corrupt and obstructionist. Carter, on the other hand, with a large partisan majority in Congress and the only one of these presidents not to face divided government, rarely made negative comments about partisanship.

When identifying virtues of partisanship or bipartisanship, Carter and Reagan tend to be more policy specific in the particular policy-related virtues they value, whereas Eisenhower stresses the general virtues of his party or bipartisanship. Eisenhower's

\section{TABLE 2}

Use of Party-Related References by President

\begin{tabular}{|c|c|c|c|c|}
\hline Nature of Reference & Eisenhower & Carter & Reagan & G. W. Bush \\
\hline Any party-related reference $(\%)$ & 43.2 & 29.2 & 53.6 & 49.2 \\
\hline \multicolumn{5}{|l|}{ As percent of party-related references: } \\
\hline Virtues of partisanship (any) & 49.7 & 55.4 & 40.8 & 14.1 \\
\hline in economic policy & 5.0 & 22.9 & 19.8 & 1.7 \\
\hline in foreign policy & 0.0 & 6.8 & 3.9 & 0.1 \\
\hline in other policy & 3.3 & 17.2 & 8.1 & 5.1 \\
\hline in general & 44.2 & 33.7 & 17.5 & 7.6 \\
\hline Virtues of bipartisanship (any) & 60.2 & 30.7 & 46.7 & 73.6 \\
\hline in economic policy & 9.9 & 7.2 & 19.4 & 20.1 \\
\hline in foreign policy & 17.7 & 11.5 & 15.6 & 11.9 \\
\hline in other policy & 5.5 & 7.5 & 10.5 & 38.6 \\
\hline in general & 38.1 & 7.0 & 7.3 & 13.6 \\
\hline $\begin{array}{l}\text { Partisanship is corrupt, extreme, obstructive; } \\
\text { congressional partisanship a problem }\end{array}$ & 14.9 & 3.0 & 36.9 & 27.4 \\
\hline Mandate for partisan/bipartisan approach & 1.7 & 5.2 & 2.8 & 0.4 \\
\hline Campaign/election-related & 13.3 & 27.7 & 26.4 & 39.3 \\
\hline
\end{tabular}

Note: Columns do not total 100 percent because each item was coded in up to three categories. "Any party-related reference" percentages are based on all items $(\mathrm{N}=4,462)$. In the remaining rows of the table, percentages are based on cases in which a party reference was made $(\mathrm{N}=1,948)$. For example, for Eisenhower, 43.2 percent of all items had a reference of some type. Of these items in which references were made, 5.0 percent made a positive reference to his party and economic policy. 
pro-party pitches, for example, are often stated as support for a system built around responsible parties that are unified, given a chance to govern effectively, and then judged on their record. General endorsements of party cooperation are similarly the most common in his bipartisan lexicon. Bush makes few partisan virtue references, so the distinction between general and specific references is not very meaningful, but his bipartisan references tend toward the specific.

The overwhelming presence of bipartisan compared to partisan appeals from Bush is at odds with his image, especially among his opponents, as a particularly partisan president. What accounts for this apparent disconnection? We offer two possible explanations. First, Bush might have used bipartisan rhetoric precisely to soften this partisan image, especially if the administration's division of labor had other individuals handle communications of a more biting partisan nature. A second possibility is that the interpretation of Bush as particularly partisan is somewhat overdrawn. Certainly on some issues and with some tactics, Bush sharply divided the parties. On the other hand, during his first term, which is the period we examine in this study, several of Bush's signature achievements - an increased national role in education, a new prescription drug entitlement, campaign finance reform-represented departures from long-standing Republican positions. Bush's success with House Democrats in his first term, measured as the percentage of votes on which a majority of Democrats voted consistent with Bush's preferred position, was about the same as Bill Clinton's and Ronald Reagan's second-term success with the opposition party and about the same as his father's success with House Democrats during his term. Looking at the Senate, Bush's first-term success rate with the opposition party was actually substantially higher than that of any president since Richard Nixon (Stanley and Niemi 2006, 260-61). Presidential success scores on congressional roll calls mark only the endpoint of lawmaking rather than the tenor of the process that led to that point, but they are suggestive that reality might be more nuanced than the perception. We can certainly conclude from presidential approval data, however, that if the goal of Bush's rhetoric was to attract bipartisan public support, Democrats were not convinced. ${ }^{12}$

Table 3 shows that these substantive differences between the four presidents are also statistically significant. With only two exceptions, when considering all items, these presidents are distinctive in the volume of their party references. The two exceptions both involve a comparison of Eisenhower and Reagan. $t$ tests indicate that Eisenhower and Reagan make references to their party's virtues and to bipartisan virtues at about the same clip (first column, Table 3). Limiting the analysis to just those items in which a partyrelated reference is made (second column, Table 3), Eisenhower and Carter make an equivalent volume of references to the virtues of partisanship. In all other comparisons, the paired presidents are significantly different.

12. The perception of how partisan a president is may depend partly on the degree of partisan polarization present at a given time. If parties are moving further apart, finding a median compromise point may be more difficult, and presidents may face criticism from within their party for moving too far toward the opposition. Both Clinton and Bush faced complaints from fellow partisans that they had deviated too far from the party's liberal or conservative orthodoxy, respectively, on several issues. In this type of polarized environment, a president like Clinton or Bush could provoke very intense partisan reactions in the legislature and public even when a legislative strategy itself was not narrowly partisan. 
TABLE 3

Comparison of Means of Presidential Communication Items (t Values)

\begin{tabular}{|c|c|c|}
\hline Comparison Set & All Items & Items with Party-Related References \\
\hline \multicolumn{3}{|l|}{ Any party-related reference } \\
\hline Eisenhower vs. Carter & $5.40 * * *$ & \\
\hline Eisenhower vs. Reagan & $-3.68 * * *$ & \\
\hline Eisenhower vs. G. W. Bush & $-2.18 * *$ & \\
\hline Carter vs. Reagan & $-12.97 * * *$ & \\
\hline Carter vs. G. W. Bush & $-11.16^{* * *}$ & \\
\hline Reagan vs. G. W. Bush & $2.25 * *$ & \\
\hline \multicolumn{3}{|c|}{ References to virtues of partisanship } \\
\hline Eisenhower vs. Carter & $2.52 * *$ & -1.26 \\
\hline Eisenhower vs. Reagan & -0.16 & $2.15 * *$ \\
\hline Eisenhower vs. G. W. Bush & $8.89 * * *$ & $11.20 * * *$ \\
\hline Carter vs. Reagan & $-3.70 * * *$ & $4.63 * * *$ \\
\hline Carter vs. G. W. Bush & $7.85 * * *$ & $16.30 * * *$ \\
\hline Reagan vs. G. W. Bush & $11.47 * * *$ & $11.70 * * *$ \\
\hline \multicolumn{3}{|c|}{ References to virtues of bipartisanship } \\
\hline Eisenhower vs. Carter & $9.32 * * *$ & $7.01 * * *$ \\
\hline Eisenhower vs. Reagan & -0.39 & $3.22 * * *$ \\
\hline Eisenhower vs. G. W. Bush & $-3.90 * * *$ & $-3.55 * * *$ \\
\hline Carter vs. Reagan & $-11.24 * * *$ & $-5.19 * * *$ \\
\hline Carter vs. G. W. Bush & $-18.23 * * *$ & $-15.36 * * *$ \\
\hline Reagan vs. G. W. Bush & $-6.23 * * *$ & $-10.54 * * *$ \\
\hline \multicolumn{3}{|c|}{ Cites partisanship as obstructionist, corrupt } \\
\hline Eisenhower vs. Carter & $6.93 * * *$ & $5.45 * * *$ \\
\hline Eisenhower vs. Reagan & $-6.43 * * *$ & $-5.69 * * *$ \\
\hline Eisenhower vs. G. W. Bush & $-3.94 * * *$ & $-3.50 * * *$ \\
\hline Carter vs. Reagan & $-17.05 * * *$ & $-13.53 * * *$ \\
\hline Carter vs. G. W. Bush & $-13.24 * * *$ & $-10.54 * * *$ \\
\hline Reagan vs. G. W. Bush & $4.38 * * *$ & $3.76 * * *$ \\
\hline
\end{tabular}

Note: $* * \mathrm{p} \leq .05, * * * \mathrm{p} \leq .01$, two-tailed. A positive $\mathrm{t}$ value indicates the first president named had a higher percentage of items making the specified type of reference.

The overview so far has emphasized the differences between presidents. We now turn to general patterns by which we expect presidents to behave similarly. We discuss our recurrent features hypotheses first descriptively and then using logistic regression. Our political environment hypotheses are more easily tested and discussed using logistic regression.

\section{Recurrent Features of the Office: Audience Signals and Campaign Calendar Hypotheses}

We argue above that party audiences and the electoral season are likely to encourage a surge of references to the party system by any president. About 39 percent of the items in which Eisenhower and Reagan make party-related references, for example, occur either before a party audience or during the final third of an election year. For Carter, the tally 
is fully 55 percent and for Bush 49 percent. Table 4 shows that the president's willingness to employ party-related references does indeed vary substantially across audiences. These four presidents relate to various audiences similarly in their likelihood of making partyrelated references. The president's relationship to these audiences and his relative likelihood of making party-related references to them reflect a recurrent institutional pattern across presidents.

Making party-related references to a party audience is close to a sure thing (see Table 4). With the media as an audience, Eisenhower and Reagan again make party references a majority of the time, but these venues are arguably those over which presidents have the least control. Are these presidents merely the victims of circumstance, referring to parties only under the prodding of journalists? No. Notwithstanding the notion that presidents seek to project a public image "above politics, beyond party, and touched by God," Table 4 indicates that all four presidents are quite willing to make party-related references to the public. Only Carter makes party references less than half the time he communicates with the public, and that just barely so. It is instead with groups of fellow national-level governmental elites-members of Congress, U.S. government officials, foreign officials - that these presidents are most reluctant to or find it least necessary to link themselves to the party system. Party-related references for all three presidents are highest before party audiences, high before public audiences, and lowest before fellow elites. These findings confirm the audience signals hypothesis.

Eisenhower, Carter, Reagan, and Bush also adjust the type of reference before different audiences in a common manner. Addressing Congress, the media, state and local officials, or national and foreign officials, when they make party-related references, each president stresses bipartisanship more than partisanship. For those audiences less directly connected to the governing process - the public, private interest groups, party groupsthere is more willingness to emphasize partisan virtues relatively more. For these three groups, we see some presidents more frequently making bipartisan than partisan references, whereas other presidents make more references to party virtues. One notable result in Table 4 is that both Eisenhower and Bush make references to the virtues of bipartisanship over half the time they mention parties even before party groups. Indeed, Bush makes more bipartisan than partisan references to this audience. Eisenhower's and Bush's rhetorical bipartisanship is so pronounced that in 47 percent of the items in which they point to the virtues of partisanship, they also add a reference to the virtues of bipartisanship. For Carter and Reagan, these dual messages occur only about 15 percent of the time.

The type of communication item, summarized in Table 5, produces patterns like those for audience type and similarly confirms the audience signals hypothesis. Although for three of the presidents party-related references are most likely during press conferences, which are, as noted above, arguably less controllable than other presidential communications, presidents also willingly portray themselves as linked to the party system. Speeches, addresses, and remarks, in which presidents almost entirely control the content, produce for each of these presidents the second highest likelihood of making a party-related reference. Regarding the content of the references, the pattern again resembles that found for audience type. Communication types that are closely linked to 


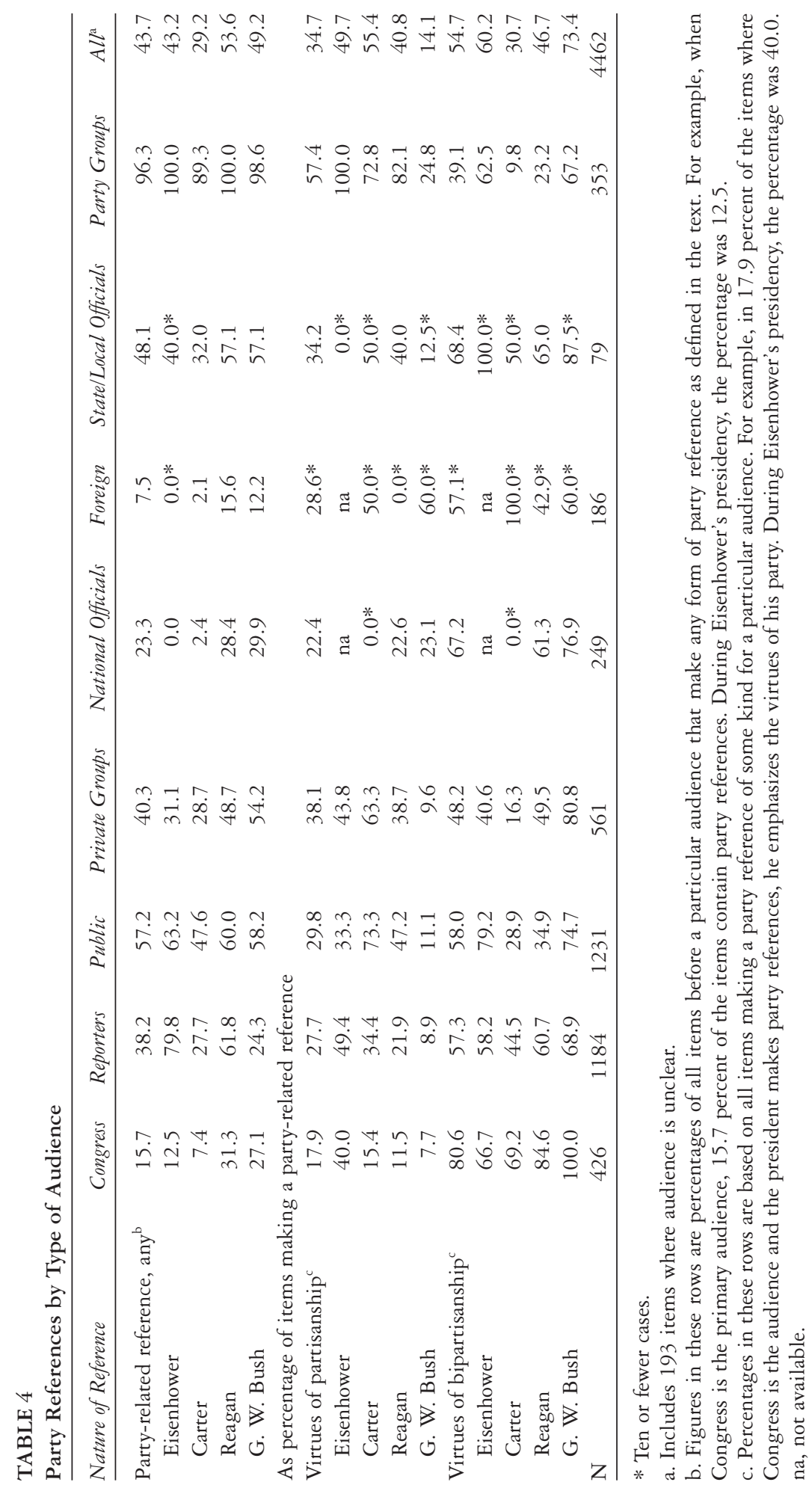


TABLE 5

Party References by Types of Presidential Communications

\begin{tabular}{|c|c|c|c|c|c|c|}
\hline \multirow[b]{2}{*}{ Nature of Reference } & \multicolumn{6}{|c|}{ Percentage of Item Making Party Reference } \\
\hline & Speech/Address & $\begin{array}{c}\text { Press } \\
\text { Conference }\end{array}$ & Bill Signing & Letter/Message & Veto Message & $A l l^{a}$ \\
\hline Party-related, any ${ }^{\mathrm{b}}$ & 46.4 & 51.0 & 34.4 & 12.9 & 6.5 & 43.7 \\
\hline Eisenhower & 44.9 & 80.4 & 6.7 & 14.5 & 0.0 & 43.2 \\
\hline Carter & 30.2 & 40.2 & 23.4 & 3.6 & $16.7 *$ & 29.2 \\
\hline Reagan & 53.3 & 74.1 & 45.2 & 24.7 & $25.0 *$ & 53.6 \\
\hline G. W. Bush & 53.6 & 23.1 & 56.6 & 12.7 & na & 49.2 \\
\hline Virtues of partisanship ${ }^{c}$ & 36.4 & 32.3 & 18.4 & 22.0 & $0.0 *$ & 34.7 \\
\hline Eisenhower & 54.0 & 47.6 & $0.0 *$ & 36.4 & na & 49.7 \\
\hline Carter & 63.7 & 38.4 & 34.6 & $50.0 *$ & $0.0 *$ & 55.4 \\
\hline Reagan & 47.6 & 22.2 & 10.5 & 15.8 & $0.0 *$ & 40.8 \\
\hline G. W. Bush & 14.5 & 12.1 & 10.0 & $0.0 *$ & na & 14.1 \\
\hline Virtues of bipartisanship ${ }^{c}$ & 53.0 & 52.9 & 80.3 & 85.4 & $0.0 *$ & 54.7 \\
\hline Eisenhower & 62.1 & 57.3 & $0.0 *$ & 72.7 & na & 60.2 \\
\hline Carter & 23.0 & 41.4 & 69.2 & $50.0 *$ & $0.0 *$ & 30.7 \\
\hline Reagan & 41.4 & 57.3 & 73.7 & 94.7 & $0.0 *$ & 46.7 \\
\hline G. W. Bush & 72.8 & 60.6 & 96.7 & $100.0 *$ & na & 73.6 \\
\hline $\mathrm{N}$ & 3219 & 649 & 221 & 319 & 46 & 4462 \\
\hline
\end{tabular}

* Ten or fewer cases.

a. Includes eight items for which item type was unclear or outside the five major categories.

b. Figures in these rows are percentages of all items of a particular type that make any form of party reference as defined in the text. For example, 46.4 percent of all speech and address items contain party references.

c. Percentages in these rows are based on all items making a party reference of some kind. For example, in 36.4 percent of the speeches in which a president makes party references, he emphasizes the virtues of his party.

na, not available.

“institutional players"-bill signings, letters, and messages—-stress bipartisanship relatively more than partisanship, whereas presidents show more willingness to refer to the virtues of partisanship in communication types linked to outside groups including the public, such as speeches, addresses, and remarks. These presidents-excluding Bush, who simply does not make many party virtue references-appear to engage in a two-level game in which, to the public, they extol the virtues of partisanship along with bipartisanship to take credit, deflect blame, and build the foundations for future success, while to institutional elites, they refrain from party-related references or emphasize the language of bipartisanship when they do make these references.

As we anticipated, the electoral calendar is connected to the president's use of party-related references, supporting the electoral calendar hypothesis. Almost 70 percent of presidential communication items between August and November of an election year (the "electoral third") make a party-related reference, nearly double the rate of all other months. About 40 percent of the items where there is a party-related reference refer to the virtues of bipartisanship during the electoral third, compared to about 60 percent during other months. Although there is variation among the presidents regarding the percentage 
TABLE 6

Estimation of Party-Related References

\begin{tabular}{|c|c|c|c|}
\hline & Any Reference & Virtues of Partisanship & Virtues of Bipartisanship \\
\hline \multirow[t]{2}{*}{ Monthly change in approval, lagged } & 0.00 & -0.02 & $0.03 *$ \\
\hline & $(0.01)$ & $(0.01)$ & $(0.01)$ \\
\hline \multirow[t]{2}{*}{ Percent of public independent } & $-0.07 * *$ & $-0.10 * *$ & $0.07 * *$ \\
\hline & $(0.03)$ & $(0.04)$ & $(0.04)$ \\
\hline \multirow[t]{2}{*}{ Number of prior month legislative wins } & $0.01 * * *$ & 0.00 & -0.01 \\
\hline & $(0.01)$ & $(0.01)$ & $(0.01)$ \\
\hline \multirow[t]{2}{*}{ Number of prior month legislative losses } & $-0.03 * *$ & -0.01 & 0.00 \\
\hline & $(0.01)$ & $(0.02)$ & $(0.02)$ \\
\hline \multirow[t]{2}{*}{ Divided government } & 0.04 & -0.34 & 0.26 \\
\hline & $(0.14)$ & $(0.23)$ & $(0.20)$ \\
\hline \multirow[t]{2}{*}{ Public is primary audience } & $0.73 * * *$ & $0.47 * * *$ & -0.19 \\
\hline & $(0.08)$ & $(0.14)$ & $(0.13)$ \\
\hline \multirow[t]{2}{*}{ Party group is primary audience } & $4.23 * * *$ & $1.79 * * *$ & $-1.00 * * *$ \\
\hline & $(0.31)$ & $(0.16)$ & $(0.15)$ \\
\hline \multirow[t]{2}{*}{ August-November of election year } & $1.21 * * *$ & $0.86 * * *$ & $-0.96 * * *$ \\
\hline & $(0.09)$ & $(0.13)$ & $(0.12)$ \\
\hline \multirow[t]{2}{*}{ Length of communication item } & $0.21 * * *$ & $0.02 *$ & 0.00 \\
\hline & $(0.02)$ & $(0.01)$ & $(0.01)$ \\
\hline \multirow[t]{2}{*}{ Jimmy Carter } & 0.31 & $1.30 * *$ & $-2.01 * * *$ \\
\hline & $(0.43)$ & $(0.60)$ & $(0.56)$ \\
\hline \multirow[t]{2}{*}{ Ronald Reagan } & $1.17 * * *$ & 0.26 & $-1.06 * * *$ \\
\hline & $(0.26)$ & $(0.37)$ & $(0.35)$ \\
\hline \multirow[t]{2}{*}{ George W. Bush } & $1.16 * *$ & -0.52 & -0.57 \\
\hline & $(0.58)$ & $(0.83)$ & $(0.75)$ \\
\hline \multirow[t]{2}{*}{ Model constant } & -0.39 & $1.69 *$ & -0.90 \\
\hline & $(0.70)$ & $(0.99)$ & $(0.90)$ \\
\hline Log pseudolikelihood & -2230.08 & -1008.33 & -1140.52 \\
\hline Model Chi' (all p <.001) & 669.33 & 283.50 & 285.82 \\
\hline Pseudo $\mathrm{R}^{2}$ & 0.25 & 0.18 & 0.13 \\
\hline $\mathrm{N}$ & 4328 & 1910 & 1910 \\
\hline
\end{tabular}

Note: $* \mathrm{p} \leq .10, * * \mathrm{p} \leq .05, * * * \mathrm{p} \leq .01$, two-tailed. The table reports unstandardized logit coefficients and robust standard errors in parentheses. Any reference equals 1 if president makes any party-related reference (coded into fifteen categories; see text for description), 0 otherwise. The partisanship and bipartisanship columns include all items where Any reference $=1$. Virtues of partisanship equals 1 if the president makes a positive reference to his party (coding categories 1-5; see text), 0 otherwise. Virtues of bipartisanship equals 1 if the president makes a positive reference to bipartisanship (coding categories 6-10; see text), 0 otherwise. Models were estimated with Stata v9.2.

of communication items during these two periods that reference bipartisanship, for each president, references to the virtues of bipartisanship are more common outside the electoral third than during, and references to the virtues of partisanship are more common during the electoral third than outside it.

We now examine our hypotheses using logistic regression. The first column of Table 6 has as its dependent variable whether a communication item makes any type of party-related reference, looking at all four presidents combined. The results support the 
audience signals hypothesis and electoral third hypothesis: having the public or party as an audience and a communication item being issued from August through November of an election year increase the probability of a party-related reference. Having the public as the primary audience, while holding all other variables at their mean values, increases the probability of a party-related reference to .60 , compared to .42 for all other audiences. Communication items outside the electoral third have a .40 probability of making a party-related reference; during the campaign, the probability rises to .69. The same pattern emerges regarding the probability of a reference to the virtues of a president's party (column 2), and for references to the virtues of bipartisanship (column 3), the results were again consistent with our hypotheses. With the party as an audience and during the electoral third, the probability that a party-related reference mentions the virtues of bipartisanship decreases from .60 to .35 for the former, and from .63 to .40 for the latter, with all other values held to the mean. The public as audience, however, had no significant effect on the probability of a bipartisan reference.

\section{Shifts in the Political Environment: The President as Statesman, the President as Politician, Public Partisanship, and Institutional Control Hypotheses}

Table 6 offers support for our political environment hypotheses. Looking at the first column that examines all party-related references, as the proportion of political Independents in the population grows, the probability of a presidential communication including a party-related reference drops, as suggested by the public partisanship hypothesis. Holding other variables to their mean values and setting the percentage of Independents to its lowest value of 22 percent produces a .70 probability of a partyrelated reference. With Independents at their highest value of 44 percent, the probability drops substantially to .33 . The president's reaction to legislative victories and defeats is consistent with the president-as-politician hypothesis, with the probability of the president linking himself to the party system increasing when that system produces legislative success and dropping when it produces losses. As losses move from 0 to 8 (about one standard deviation above the mean), the probability of a party-related reference drops from .50 to .44 . Moving the number of wins similarly from 0 to 22 increases the probability from .43 to $.51 .^{13}$ Finally, contrary to the president-asstatesman and institutional control hypotheses, we find no significant relationship between changes in presidential approval or divided government and the probability of party-related references.

Limiting our analysis again to the probability of a reference to the virtues of partisanship or bipartisanship, the public partisanship hypothesis is again confirmed: presidents deemphasize the virtues of party (second column of results) and emphasize the virtues of bipartisanship (third column of results) when the proportion of Independents in the public grows. For references to partisan virtues, the probability drops from .63 to .17 as the percentage of Independents moves from the minimum to the maximum, while

13. A very good month (wins set at 22 , losses at 0 ) produces a probability of .53 , while a bad month (0 wins, 8 losses) is at .40 . 
for bipartisan virtue, the probability rises from .31 to .69. And here the institutional control hypothesis is correctly signed - the presence of divided government reduces the probability of references to the virtue of party and increases that of references to bipartisan virtues-but not statistically significant.

\section{Party-Related References by Individual Presidents}

To this point, we have examined presidential use of party-related references across these four presidents. We now discuss the general deployment of party-related references and the specific references to partisan and bipartisan virtues by each president. Considering first the recurrent features of the office, we find substantial support in Table 7 for our audience signals and campaign calendar hypotheses for each president.

TABLE 7

Estimation of Party-Related References by Individual Presidents

\begin{tabular}{|c|c|c|c|c|}
\hline & Eisenhower & Carter & Reagan & G. W. Bush \\
\hline Monthly change in approval, lagged & $\begin{array}{c}-0.03 \\
(0.02)\end{array}$ & $\begin{array}{c}0.01 \\
(0.01)\end{array}$ & $\begin{array}{c}-0.06 * * \\
(0.03)\end{array}$ & $\begin{array}{c}0.00 \\
(0.01)\end{array}$ \\
\hline Percent of public independent & $\begin{array}{r}-0.29 \\
(0.24)\end{array}$ & $\begin{array}{l}0.42 * * * \\
(0.15)\end{array}$ & $\begin{array}{r}-0.03 \\
(0.04)\end{array}$ & $\begin{array}{c}-0.36 * * * \\
(0.06)\end{array}$ \\
\hline Number of prior month legislative wins & $\begin{array}{c}0.02 \\
(0.02)\end{array}$ & $\begin{array}{l}0.03 * * * \\
(0.01)\end{array}$ & $\begin{array}{c}0.01 \\
(0.01)\end{array}$ & $\begin{array}{l}0.03 * \\
(0.02)\end{array}$ \\
\hline Number of prior month legislative losses & $\begin{array}{l}-0.15 * * * \\
(0.05)\end{array}$ & $\begin{array}{l}-0.06 * * * \\
(0.02)\end{array}$ & $\begin{array}{c}0.00 \\
(0.02)\end{array}$ & $\begin{array}{r}-0.03 \\
(0.04)\end{array}$ \\
\hline Divided government & & & & $\begin{array}{c}-0.83 * * * \\
(0.25)\end{array}$ \\
\hline Public is primary audience & $\begin{array}{l}0.84 * * \\
(0.34)\end{array}$ & $\begin{array}{l}0.65 * * * \\
(0.19)\end{array}$ & $\begin{array}{l}0.73 * * * \\
(0.16)\end{array}$ & $\begin{array}{l}0.82 * * * \\
(0.14)\end{array}$ \\
\hline Party group is primary audience & & $\begin{array}{l}3.51 * * * \\
(0.37)\end{array}$ & & $\begin{array}{l}4.91 * * * \\
(0.73)\end{array}$ \\
\hline August-November of election year & $\begin{array}{l}0.88 * * * \\
(0.24)\end{array}$ & $\begin{array}{l}1.48 * * * \\
(0.17)\end{array}$ & $\begin{array}{l}0.93 * * * \\
(0.19)\end{array}$ & $\begin{array}{l}1.52 \text { *** } \\
(0.20)\end{array}$ \\
\hline Length of communication item & $\begin{array}{c}0.13 \\
(0.15)\end{array}$ & $\begin{array}{l}0.11 * * * \\
(0.03)\end{array}$ & $\begin{array}{l}0.33 * * * \\
(0.03)\end{array}$ & $\begin{array}{l}0.28 * * * \\
(0.03)\end{array}$ \\
\hline Model constant & $\begin{array}{l}5.31 \\
(5.69)\end{array}$ & $\begin{array}{c}-18.19 * * * \\
(5.78)\end{array}$ & $\begin{array}{c}-0.93 \\
(1.33)\end{array}$ & $\begin{array}{l}12.87 * * * \\
(2.64)\end{array}$ \\
\hline Log pseudolikelihood & -243.70 & -604.10 & -634.27 & -681.13 \\
\hline Model Chi ${ }^{2}($ all $\mathrm{p}<.001)$ & 29.39 & 221.18 & 160.05 & 335.91 \\
\hline Pseudo $\mathrm{R}^{2}$ & 0.09 & 0.24 & 0.16 & 0.32 \\
\hline $\mathrm{N}$ & 397 & 1300 & 1085 & 1435 \\
\hline
\end{tabular}

Note: $* \mathrm{p} \leq .10, * * \mathrm{p} \leq .05, * * * \mathrm{p} \leq .01$, two-tailed. The table reports unstandardized logit coefficients and robust standard errors in parentheses. The dependent variable in all models is coded 1 if the president makes a party-related reference, 0 otherwise. "Divided government" is omitted for Eisenhower, Carter, and Reagan due to multicollinearity. "Party group is primary audience" is omitted for Eisenhower and Reagan because it perfectly predicts the dependent variable. Models were estimated with Stata v9.2. 
Partisan and public audiences increase the probability of party-related references, and all four presidents are much more likely to make party-related references during the electoral third.

We again find support for our political environment hypotheses. Due to collinearity, we could only test the institutional control hypothesis for Bush, but we find a strong significant decrease in the probability of Bush making a party-related reference during the divided government portion of his presidency. The president-as-politician hypothesis is supported, with Presidents Carter and Bush significantly increasing the probability of making a party-related reference as legislative victories increase, and Eisenhower and Carter significantly decreasing that probability in response to defeats. Sensitivity to their political standing in Congress is substantial and significant: the greater the number of recent legislative victories, the greater the probability of rhetorical linkage to the party system; the greater the number of losses, the greater the probability of delinkage. For Carter, the probability of a party-related reference rises from .20 to .28 as his monthly victories increase from 0 to their mean of 16, while the probability drops from .34 to .28 as his losses mount from 0 to the mean of 5 (with all other variables set to their mean values). The probability drops further to .17 when his losses are set at his maximum of 16. On the other hand, although signed correctly for Eisenhower and effectively a coefficient of zero for Carter and Bush, the president as statesman hypothesis is significantly supported only for Reagan, whose probability of a party-related reference drops as his approval increases. Except for Reagan, then, these presidents neither significantly entangle nor disentangle themselves from party references as their approval ratings rise. Finally, the coefficient for partisanship among the public is correctly signed but not significant for two presidents, is correctly signed and significant for Bush, but is both incorrectly signed and significant for Carter. With Carter, more Independents in the public led to heightened, not reduced, probability of a party-related statement.

Table 8 looks at, for each president, the subsets of party system references that emphasize party virtues and bipartisan virtues. Again, the recurrent features of the office hypotheses, audience signals and the electoral calendar, perform very well, especially for Carter and Reagan. The political environment hypotheses generally do not fare well-in most cases, coefficients are not significant. Three coefficients are significant for Eisenhower and Reagan, while one is significant and incorrectly signed for Eisenhower. Both Eisenhower and Reagan have reduced probabilities of referring to party virtues when their approval rating has been increasing.

One striking pattern in Table 8 is for President Bush. As noted earlier, his rhetoric is overwhelmingly bipartisan, meaning there is relatively little variance to explain in his case compared to the others. Among the recurrent features variables, only the party audience is significant, with the probability of a party virtue reference increasing before this audience. For references to bipartisan virtues, the probability of a reference increases as legislative victories mount, which is consistent with our president-as-politician hypothesis. However, Bush also increases the probability of a bipartisan reference when his approval rating increases, which is contrary to our president-as-statesman hypothesis, where we predicted that, as their approval rose, presidents would seek to rhetorically "rise above party." 


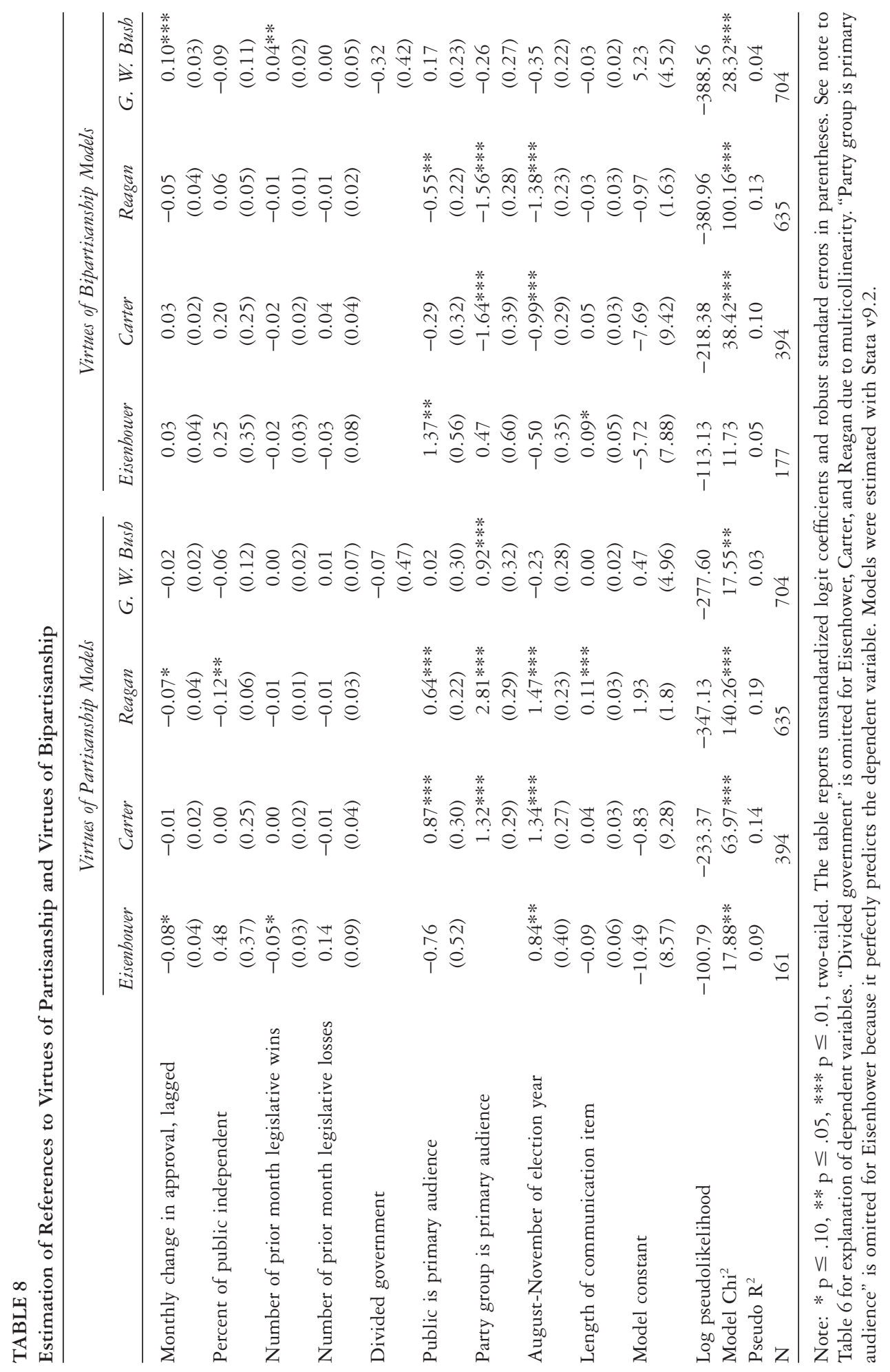




\section{A Note on Political Time and Presidential Rhetoric}

One analytically helpful description of the broad, historical context facing presidents is Stephen Skowronek's (1993) notion of "political time." Although particular features of the political time framework may be problematic, it provides a useful heuristic to categorize basic scenarios under which presidents assume the office. ${ }^{14}$ Skowronek's model suggests that a president's leadership tasks will be heavily determined by the strength of the ongoing policy regime and by the president's relationship to that regime. These two variables produce four elemental presidential types. "Preemptive" presidents serve during a political era dominated by the policies and approaches of the opposition party. "Disjunctive" presidents are at the helm during the collapse of their party's dominance. A "reconstructive" president has the opportunity to reshape national policy priorities and his party's agenda as the policy regime of his opponents becomes discredited. And "articulative" presidents inherit the popular policy regime of their party and act as managers and caretakers on behalf of that regime and the coalition supporting it.

We briefly consider here whether these types are useful for understanding how presidents rhetorically connect themselves to the party system. Although Skowronek does not explicitly link his leadership categories to rhetoric patterns, our reading suggests that a reconstructive president would need to dismantle the previous regime, loosen opposition partisans in Congress and the public from their traditional moorings, and encourage the loyalty of his party's members. To accomplish these tasks, his party-related references should contain a mix of references to partisan and bipartisan virtues, seasoned with a substantial measure of criticism about the failings of "typical partisan politics." Conversely, one might expect an articulative president, working within the presumably politically successful "revolution" introduced by his reconstructive predecessor, to be more partisan in his references than was the reconstructive president. The articulative leader, viewing himself as continuing to implement and refine the popular program of the reconstructive president, might, like his predecessor, aggressively criticize the other party's obstructionism. A preemptive president holds a precarious position, working under the umbrella of a resilient policy regime that he does not embrace. References should tilt toward the virtues of bipartisanship. Although we would anticipate partisan politics to frustrate this president, he has to be cautious about seeming to blame the other party, given his need for bipartisan cooperation to get much accomplished. We expect he will not target partisan politics for criticism to the degree the reconstructive and articulative presidents will. Lastly, with the opposition party sensing tremendous strategic opportunities by allowing the governing ship to sink of its own weight, a disjunctive president would likely find relatively little advantage in emphasizing bipartisanship over other party references, choosing instead to extol predominantly the virtues of partisanship as he attempts to rally the party faithful around the decaying policy regime.

14. One possible complaint is that the historical conditions facing presidents, particularly the resiliency of the dominant policy regime, are more evident in retrospect than they might have been at the time the president took office. It is also unclear whether the framework is deterministic: could presidents taking office under disjunctive conditions succeed, or are they destined to fail no matter what their actions? 
In sum, our reading of Skowronek leads us to expect preemptive presidents to make relatively more bipartisan references and disjunctive relatively more partisan references. Reconstructive and articulative presidents would have more balance, but articulative presidents would likely make more references to partisan virtues than would reconstructive presidents. Disjunctive presidents should be the least likely to complain about partisanship.

Looking back to Table 2, these expectations mostly are met. Eisenhower, the preemptive president, is more likely to emphasize the virtues of bipartisanship than the virtues of partisanship. He does, however, make more pro-party appeals than the preemptive archetype might imply. This finding is in keeping with the revisionist view of Eisenhower as a politically engaged and attentive president. Carter, the disjunctive president, tilts toward references to partisan virtue. He is also, as expected, the least likely to register complaints about the nature of party politics. Reagan, the reconstructive president, is the most balanced in his use of partisan and bipartisan references, leaning slightly toward the latter. Regarding complaints about partisanship, the presidents are ordered as we would expect in the political time framework: the reconstructive and articulative presidents are the most critical, the preemptive less so, and the disjunctive least of all. We cannot directly test, however, whether political time explains this ordering or is merely consistent with it.

The glaring exception to our application of Skowronek's (1993) typology is George W. Bush's heavy emphasis on references to the virtues of bipartisanship. Our reading of the political time framework led us to suggest that this type of president, following in the footsteps of the reconstructive president, should tilt more toward references to partisan than bipartisan virtues. Skowronek's archetypical articulative president is likely to serve with his party controlling Congress, perhaps by substantial margins, which was clearly not Bush's experience. However, divided government, although related to the probability of Bush making a party-related reference, was not significantly related to whether that reference would tout the virtues of his party or bipartisanship.

Bush's use of bipartisan references also does not appear to be an effect of September 11 alone. To examine this possibility, we divided 2001 into four-month blocks (January to April, May to August, and September to December) and examined those communication items making a party-related reference. From the first to the final third, respectively, 79.6 percent, 72.2 percent, and 92.3 percent of Bush's party-related references invoked the virtues of bipartisanship. There is a jump in the final third, but references to bipartisanship were already quite high prior to 9/11. In 2002, the figures were 76.2 percent and 87.2 percent for the first two thirds and 53.2 during the electoral third.

\section{Conclusion}

Do presidents link themselves rhetorically to the party system or do they attempt to portray themselves as above politics and beyond party? Looking at simple percentages, Bush and Reagan refer to party in about half their communication items, Eisenhower in 
two fifths, and Carter in about one third. Clearly, under particular conditions, these presidents were highly willing to link themselves to, refer to, praise, criticize, and discuss the party system. Even referring to the party system one third of the time is, we believe, a greater frequency than is implied by the notion that presidents seek to portray a statesman-like image above the political fray. Theories and arguments in the presidency literature assuming that contemporary presidents assiduously depict themselves as above politics and party may require revision. These four presidents are a small sample, but they are a diverse group (see Table 1), and we suspect they represent a broader pattern among contemporary presidents.

Presidents employ party-related references and bipartisan and partisan virtue references in comparable fashion across types of audiences and types of presidential communications. They are, for instance, likely to make more party-related references to the public than to elites, and these public references are more likely to emphasize partisan virtues rather than the bipartisan virtues more often proffered to elite audiences. These findings are again difficult to square with many of the presumptions in the literature about the nature of presidential appeals to the public. Rather than attempting to appear beyond party to the public, it is precisely to the public that presidents largely make these party-related linkages. When presidents go public, they do not necessarily go there partyless.

Rather than a definitive rhetorical embrace or snub, presidents adjust their use of party system references and the content of these references in a strategic manner. Our most consistent results were for the importance of recurrent features of the office, as tested in the audience signals and campaign calendar hypotheses. Public and party audiences, but not elite official audiences, and the months of electoral campaigns increased the probability that presidents would use party-related references in general and references to the virtues of partisanship and bipartisanship more specifically. When looking at all party-related references by all four presidents combined, we found solid support for several of our hypotheses related to presidents' navigation of the shifting political environment. In particular, a rising share of political Independents discouraged the use of party-related references, but among the references used, those discussing the virtues of bipartisanship increased. And these presidents strategically tended to detach themselves rhetorically from parties when the legislative process failed them and attach themselves when that process produced victories, as our president as politician hypothesis expected. Support for the president as tribune notion that presidents would distance themselves from parties as their approval rating rose was limited throughout the analysis. Overall, the results for the political environment hypotheses were strongest when looking at all party-related references for all presidents, and more mixed when looking at the rhetorical use of virtues of partisanship and bipartisanship by individual presidents.

There are several possible directions for research into presidents' employment of party-related language. We have not looked here at whether the president's portrayal of his bipartisan and partisan linkages has any direct impact on, for example, future approval ratings or winning percentages in Congress. Given the admittedly mixed results in the existing literature concerning the link between presidential speech, approval, and success in Congress, it may be reasonable to speculate that the party-related content of 
these speeches and activities might also have some impact, at least for a window of time. Because definition of the president's public image is only partly controlled by the president and his team, analysis of the impact of presidential communication might also consider how the media parses a president's party-related messages. Whether the president's messages about partisanship and bipartisanship are consistent with his legislative behavior or, instead, an exercise in "cheap talk" (Devitt 1997), and what strategic purpose would be served either way, is another possible line of inquiry. The findings here suggest that any of these explorations should begin from the premise that presidents do not adopt a monolithic "above the fray" rhetorical posture but, rather, strategically portray themselves as linked or not to the party system.

\section{References}

Aldrich, John H. 1995. Why parties? The origins and transformation of party politics in America. Chicago: University of Chicago Press.

Barrett, Andrew. 2005. Going public as a legislative weapon: Measuring presidential appeals regarding specific legislation. Presidential Studies Quarterly 35: 1-10.

Binder, Sarah A. 1999. The dynamics of legislative gridlock, 1947-96. American Political Science Review 93: 519-33.

Bond, Jon R., and Richard Fleisher. 1990. The president in the legislative arena. Chicago: University of Chicago Press.

Brace, Paul, and Barbara Hinckley. 1993. Presidential activities from Truman through Reagan: Timing and impact. Journal of Politics 55: 382-98.

Brady, David W., and Craig Volden. 1998. Revolving gridlock: Politics and policy from Carter to Clinton. Boulder, CO: Westview Press.

Burns, James MacGregor. 1963. The deadlock of democracy. Englewood Cliffs, NJ: Prentice-Hall.

Cameron, Charles M. 2000. Veto bargaining: Presidents and the politics of negative power. New York: Cambridge University Press.

Campbell, James E. 1993. The presidential pulse of congressional elections. Lexington: University Press of Kentucky.

Canes-Wrone, Brandice. 2006. Who leads whom? Presidents, policy, and the public. Chicago: University of Chicago Press.

Cohen, Jeffrey E. 1995. Presidential rhetoric and the public agenda. American Journal of Political Science 39: 87-107.

Cohen, Jeffrey E., and John A. Hamman. 2003. The polls: Can presidential rhetoric affect the public's economic perceptions? Presidential Studies Quarterly 33: 408-22.

Coleman, John J. 1996. Party decline in America: Policy, politics, and the fiscal state. Princeton, NJ: Princeton University Press.

- 1999. Unified government, divided government, and party responsiveness. American Political Science Review 93: 821-35.

Collier, Kenneth, and Terry Sullivan. 1995. New evidence undercutting the linkage of approval with presidential support and influence. Journal of Politics 57: 197-209.

Conti, Delia B. 1995. President Reagan's trade rhetoric: Lessons for the 1990s. Presidential Studies Quarterly 25: 91-108.

Cox, Gary W., and Mathew D. McCubbins. 1993. Legislative leviathan: Party government in the House. Berkeley: University of California Press.

Davis, James W. 1992. The president as party leader. New York: Praeger.

Devitt, James. 1997. Framing politicians: The transformation of candidate arguments in presidential campaign news coverage, 1980, 1988, 1992, and 1996. American Behavioral Scientist 40: 1139-60.

Druckman, James N., and Dustin W. Holmes. 2004. Does presidential rhetoric matter? Priming and presidential approval. Presidential Studies Quarterly 34: 755-78. 
Edwards, George C. III. 1989. At the margins: Presidential leadership of Congress. New Haven, CT: Yale University Press.

Edwards, D. Clark. 1995. Predicting presidential decision-making from presidential language and mass media reportage. Presidential Studies Quarterly 25: 43-65.

Edwards, George C. III. 2003. On deaf ears: The limits of the bully pulpit. New Haven, CT: Yale University Press.

Edwards, George C. III, and Stephen J. Wayne. 1990. Presidential leadership: Politics and policy making, 2d ed. New York: St. Martin's.

Edwards, George C. III, and B. Dan Wood. 1999. Who influences whom? The president, Congress, and the media. American Political Science Review 93: 327-44.

Edwards, George C. III, William Mitchell, and Reed Welch. 1995. Explaining presidential approval: The significance of issue salience. American Journal of Political Science 39: 108-34.

Fett, Patrick J. 1992. Truth in advertising: The revelation of presidential legislative priorities. Western Political Quarterly 45: 895-920.

Geer, John G. 1998. Campaigns, party competition, and political advertising. In Politicians and party politics, edited by John G. Geer. Baltimore: Johns Hopkins University Press.

Gilmour, John B. 1995. Strategic disagreement: Stalemate in American politics. Pittsburgh: University of Pittsburgh Press.

Gleiber, Dennis W., and Steven A. Shull. 1992. Presidential influence in the policymaking process. Western Political Quarterly 45: 441-67.

Hager, Gregory L., and Terry Sullivan. 1994. President-centered and presidency-centered explanations of presidential public activity. American Journal of Political Science 38: 1079-103.

Harmel, Robert. 1984. The Roots of President-Party Relations: Intellectual, Conceptual, and Contextual. In Robert Harmel, ed., Presidents and their parties: Leadership or neglect? New York: Praeger.

Hart, Roderick P. 1987. The sound of leadership: Presidential communication in the modern age. Chicago: University of Chicago Press.

Hetherington, Marc J. 1996. The media's role in forming voters' national economic evaluations in 1992. American Journal of Political Science 40: 372-95.

Hinckley, Barbara. 1990. The symbolic presidency. New York: Routledge.

James, Scott C. 2000. Presidents, parties, and the state: A party system perspective on democratic regulatory choice, 1884-1936. New York: Cambridge University Press.

Jarvis, Sharon E. 2004. Partisan patterns in presidential campaign speeches, 1948-2000. Communication Quarterly 52: 403-19.

Jones, Charles O. 1994. The presidency in a separated system. Washington, DC: Brookings.

1999. Separate but equal branches: Congress and the presidency, 2d ed. New York: Chatham House.

Kernell, Samuel. 1986. Going public: New strategies of presidential leadership. Washington, DC: CQ Press.

Krehbiel, Keith. 1998. Pivotal politics: A theory of U.S. lawmaking. Chicago: University of Chicago Press.

Krosnick, Jon A., and Donald R. Kinder. 1990. Altering the foundations of support for the president through priming. American Political Science Review 84: 497-512.

Lewis, David. 1997. The two rhetorical presidencies: An analysis of televised presidential speeches, 1947-1991. American Politics Quarterly 25: 380-95.

Lim, Elvin T. 2002. Five trends in presidential rhetoric: An analysis of rhetoric from George Washington to Bill Clinton. Presidential Studies Quarterly 32: 328-66.

McGraw, Kathleen M., Samuel Best, and Richard Timpone. 1995. "What they say or what they do?" The impact of elite explanation and policy outcomes on public opinion. American Journal of Political Science 39: 53-74.

Milkis, Sidney M. 1993. The president and the parties: The transformation of the American party system since the New Deal. New York: Oxford University Press.

Miroff, Bruce. 1995. The presidency and the public: Leadership as spectacle. In The presidency and the political system, 4th ed., edited by Michael Nelson. Washington, DC: CQ Press.

Mouw, Calvin, and Michael MacKuen. 1992. The strategic configuration, personal influence, and presidential power in Congress. Western Political Quarterly 45: 579-608.

Neustadt, Richard E. 1990. Presidential power and the modern presidents: The politics of leadership from Roosevelt to Reagan. New York: Free Press. 
O'Neill, Tip (with William Novak). 1987. Man of the House: The life and political memoirs of Speaker Tip O’Neill. New York: Random House.

Ostrom, Charles W., and Dennis M. Simon. 1989. The man in the Teflon suit? The environmental connection, political drama, and popular support in the Reagan presidency. Public Opinion Quarterly 53: 353-87.

- 1990. Managing popular support: The presidential dilemma. In Analyzing the presidency, 2d ed., edited by Robert E. DiClerico. Guilford, CT: Dushkin.

Pauley, Garth E. 1998. Rhetoric and timeliness: An analysis of Lyndon B. Johnson's voting rights address. Western Journal of Communication 62: 26-53.

Peterson, Mark A. 1990. Legislating together: The White House and Capitol Hill from Eisenhower to Reagan. Cambridge, MA: Harvard University Press.

Petrocik, John R. 1996. Issue ownership in presidential elections, with a 1980 case study. American Journal of Political Science 40: 825-50.

Ragsdale, Lyn. 1987. Presidential speechmaking and the public audience: Individual presidents and group attitudes. Journal of Politics 49: 704-36.

- 1995. Studying the presidency: Why presidents need political scientists. In The presidency and the political system, 4th ed., edited by Michael Nelson. Washington, DC: CQ Press.

Rockman, Bert A. 1984. The leadership question: The presidency and the American system. New York: Praeger.

Roelofs, H. Mark. 1992. The prophetic president: Charisma in the American political tradition. Polity 25: $1-20$.

Rose, Richard. 1988. The postmodern president: The White House meets the world. Chatham, NJ: Chatham House.

Rottinghaus, Brandon. 2006. Rethinking presidential responsiveness: The public presidency and rhetorical congruency, 1953-2001. Journal of Politics 68: 720-32.

Schattschneider, E. E. 1942. Party government. New York: Holt Rinehart.

Seligman, Lester G., and Cary R. Covington. 1989. The coalitional presidency. Chicago: Dorsey Press.

Shields, Todd G., and Robert K. Goidel. 1998. Taking credit and avoiding blame: Good news, spin control, and democratic accountability. Political Communication 15: 99-115.

Skowronek, Stephen. 1993. The politics presidents make: Leadership from John Adams to George Bush. Cambridge, MA: Harvard University Press.

Stanley, Harold W., and Richard G. Niemi. 2006. Vital statistics on American politics 2005-2006. Washington, DC: CQ Press.

Tulis, Jeffrey K. 1987. The rhetorical presidency. Princeton, NJ: Princeton University Press.

Wayne, Stephen J. 1998. With enemies like this, who needs friends? Presidential Studies Quarterly 28: 773-79.

Whittington, Keith E. 1997. The rhetorical presidency, presidential authority, and President Clinton. Perspectives on Political Science 26: 199-207.

Wood, B. Dan, Chris T. Owens, and Brandy M. Durham. 2005. Presidential rhetoric and the economy. Journal of Politics 67: 627-45.

Zarefsky, David. 2004. Presidential rhetoric and the power of definition. Presidential Studies Quarterly 34: $607-19$

\section{Appendix}

\section{Examples of Partisan and Bipartisan References by Jimmy Carter}

Partisan References

- "The Democratic party . . want[s] to have a fair and equitable tax system." February 20, 1978, p. 386* 
- "With the help of a fine Democratic Congress on the Hill, we were able to put into law some very effective programs that were able to cut down on unemployment." April 5, 1978 , p. 685

- "We added more than four million net jobs in the U.S. in one year thanks to you, thanks to the Democratic Congress." April 28, 1979, p. 797

- "During the past 18 months the Democratic Congress and this administration have recognized the profound need of American farmers to have a chance to meet two basic requirements." August 4, 1978, p. 1375

- "I am a Democrat. . . . And I see some things that are special in my own party that make me proud." September 22, 1978, p. 1579

\section{Bipartisan References}

- "Everyone would agree that [passage of a civil service reform bill] would have been impossible without bipartisan support." October 13, 1978, p. 1761

- Alaska Public Lands policy "is not a partisan issue." May 3, 1979, p. 774

- "Both Democrats and Republicans, who put aside partisanship in order to work harmoniously for the best interests of our nation." July 26, 1979, p. 1311

- "Whether you might be Republican or Democrat or Protestant or Catholic or Jewish . . . we need to unite with a common effort." August 18, 1979, p. 1468

- "[The Panama Canal treaties are] a pure example of a bipartisan approach to a difficult political issue." February 10, 1978, p. 296

* Page numbers refer to the beginning page of the item in the Public Papers of the Presidents for the appropriate year. 